\title{
Microbiological and physicochemical changes during ripening of Camembert cheeses made from raw and pasteurized cow milk produced in Tizi-Ouzou (north of Algeria)
}

\author{
Hillal Sebbane $^{1}$, Dalila Almi ${ }^{1}$, Sonia Hadouchi ${ }^{2}$, Louiza Hedjel ${ }^{2}$, Noria Smail-Saadoun ${ }^{3}$ and Abderrahmane Mati ${ }^{1}$ \\ Received: 01 August 2020 / Accepted: 10 November 2020 / Published online: 28 February 2021 \\ (c) Indian Dairy Association (India) 2021
}

\begin{abstract}
This study was carried out on two types of Camembert produced in the region of Tizi-Ouzou (northern Algeria), one artisanal (AC) made from raw milk and the other industrial (IC) made from pasteurized milk. This work shows the effect of milk quality and cheese making processes on the progress of physicochemical and microbiological parameters throughout a maturation period of 12 days. The result shows that the repining microflora and undesirable microbial populations were significantly higher $(\mathrm{P}<0.05)$ in the artisanal Camembert $(\mathrm{AC})$ than in the industrial Camembert (IC). The physicochemical and microbiological parameters, during the ripening of the cheeses developed in a similar way with significant differences according to the type and the stage of maturation. During the cheese repining period, $\mathrm{AC}$ showed more extensive $(\mathrm{P}<0.05)$ lipolysis and proteolysis than IC. SDS-PAGE of water-soluble proteins (WSP) and insoluble fractions showed more extensive degradation of $\alpha$ s-casein $(\alpha \mathrm{s}-\mathrm{CN})$ than $\beta$-casein $(\beta-\mathrm{CN})$. The WSP profile, analyzed by Reversed-Phase High Performance Liquid Chromatography (RP-HPLC), was highest in AC than IC. The highest WSP profile was recorded at the 12th day of repining. The pathogenic flora decreased during the maturation process in AC. This development was confirmed by the results of the antibacterial effect of WSP, performed by the disc diffusion
\end{abstract}

\footnotetext{
${ }^{1}$ Laboratory of Analytical Biochemistry and Biotechnology (LABAB), Mouloud Mammeri University, Tizi Ouzou, Algeria ${ }^{2}$ Faculty of Biological Sciences and Agronomic Sciences, Mouloud
Mammeri University, Tizi Ouzou, Algeria

${ }^{3}$ Natural Resources Laboratory, Mouloud Mammeri University, Tizi Ouzou, Algeria

Hillal Sebbane $(\square)$

Laboratory of Analytical Biochemistry and Biotechnology (LABAB), Mouloud Mammeri University, Tizi Ouzou, Algeria

Email: hillalmicrobio@yahoo.com
}

technique on Escherichia coli and Staphylococcus aureus strains. From this study, it can be concluded that $\mathrm{AC}$ has a better organoleptic quality, safe for the Algerian consumer and more profitable for the Algerian cheesemakers

Keywords: Algeria, Camembert, Cheese ripening, Lipolysis, Proteolysis, Raw and pasteurized milks

\section{Introduction}

Since the early 1990s, Algeria has implemented a dairy policy in order to enhance the value of local production from cattle breeding (Mamine et al. 2011). With the launch of the National Agricultural Development Plan (NADP) in 2000 and its extension to rural areas, total milk production increased from 1.9 billion liters in 2004 to 3.3 billion in 2018 , covering about $60 \%$ of national milk needs. This production, even if it faces an insufficient collection circuit (Kali et al. 2011), has enabled some artisanal dairy farmers to process milk into raw milk cheese production. Nevertheless, this approach is quite innovative in Algeria and the microbiological and physicochemical characterization of raw milk cheeses is attracting the interest of public authorities and researchers (Aissaoui et al. 2011; Meribai et al. 2017). Indeed, hygiene requirements have become an important consideration in the production of artisanal cheeses, particularly those with a protected designation of origin (PDO), which are produced with raw milk, such as Camembert de Normandie (France), often produced in mountain areas (Gérard, 2015).

Traditional cheese making, especially for the Camembert, is distinguished from the industrial production by various aspects, and the better organoleptic qualities are obtained with the raw milk (Richard and Zadi 1983). Organoleptic properties are mainly influenced by the growth of lactic acid bacteria and the combined effect of proteolysis and lipolysis on the cheese matrix during the ripening process (Gebreyowhans et al. 2020). The release of bacteriocins and bioactive peptide fractions, endowed with antibacterial activities, inhibit bacterial pathogens (Mane and McSweeney, 2019), such as Listeria ssp. in the case of Camembert (Wan et al. 1997).This is how we set out to evaluate the quality of two soft cheeses, one made from raw milk and the other from pasteurized milk. We particularly explored the physicochemical 
and microbiological characteristics of these cheeses at different stages of the ripening process and demonstrate the safety of raw milk cheeses, especially Camembert, in Algeria. To the best of our knowledge, this is the first study to assess the antimicrobial effect of water-soluble peptide fractions extracted from Camembert.

\section{Materials and Methods}

\section{Sampling procedure and cheesemaking}

The samples of milk used for the production of Camembert, came from two farms in the region of Tizi-Ouzou. The farms are made up of cows of dairy cattle breeds (Holstein and Montbéliard), with an average age of 4 to 8 years and they are at the same stage of lactation. The maturing period is set at 12 days, with reference to Algerian industrial practices. Two types of Camembert, one artisanal, the other industrial, produced in the region of TiziOuzou (northern Algeria), were selected within the framework of this study. The analyses were based on 108 samples from each Camembert type and on 27 samples from each kind of milk (raw and pasteurized). The sampling of the products were carried from March to June during the period 2014-2016, in order to avoid the seasonality effect on the physicochemical and microbiological composition of the milk. Three samples per month were collected from each milks (raw and pasteurized milk) and cheeses at four ripening stages: first, fourth, sixth and twelfth days (Table 1). Placed in a cooler, the samples were directly taken to the laboratory and the analyses were performed during the following 24 hours.

The moulding of the cheeses (AC and IC) was performed into polyurethane perforated moulds (cylinders 10 to $11 \mathrm{~cm}$ in diameter and 13 to $14 \mathrm{~cm}$ in height). Demoulding of cheeses (AC and IC) is carried out when the lactic acidity of the curd reaches values of 9.5 to $11 \%(\mathrm{w} / \mathrm{w})$ and a $\mathrm{pH}$ of 4.5 to 4.9 .

The artisanal Camembert (AC), made from raw milk, was produced in the locality of Ouacif (Tizi-Ouzou, Algeria) by an artisan cheesemaker breeding dairy cattle under extensive holding conditions and transforms milk to Camembert according to the guidelines of the French legislation related to cheeses and cheese specialties (Art. 9 and 14 of the decree $n^{\circ} 2013-1010$ of the $12^{\text {th }}$ of November 2013). Milk was heated up to $35^{\circ} \mathrm{C}$ till it reaches an acidity of 22 to $25^{\circ} \mathrm{D}$ ( 2.2 to $2.5 \mathrm{~g} / \mathrm{l}$ of lactic acid) or at $\mathrm{pH} 6.30$ to 6.35 , before a liquid rennet (standard strength of 1:10000, Halal calf Rennet, Chr. Hansen Inc., Danemark) was added (15-20 ml/ 100 L of milk). After coagulation (1h10 min-1h30 min), the moulding of the cheese was performed directly with a ladle into polyurethane perforated moulds, without stirring the curd, at a rate of 5 ladles per mould, with a rest period of 15 to 20 minutes between each ladle, without stirring the coagulum. Draining was done on stainless drains $\left(24\right.$ to $\left.48 \mathrm{~h}, 25-28^{\circ} \mathrm{C}\right)$ at a relative humidity (RH) of $95 \%$, turning the cheese every five hours, before it was worked with sprinkling of fine salt. Then, the cheese (AC) was sprayed with a solution of Penicillium camemberti spores $\left(2 \times 10^{4}\right.$ spore $/ \mathrm{ml}$ ) and ripened during 12 days at a temperature of 10 to 12 ${ }^{\circ} \mathrm{C}$ and a $\mathrm{RH}$ of 90 to $95 \%$, with a rotation every two to three days.

The industrial Camembert (IC), made from pasteurized milk, was produced in a cheese dairy located in Draa Ben Khedda (TiziOuzou), which was supplied with milk from a close locality (Freha, Tizi-Ouzou). Without undergoing any standardization of fat and protein contents, milk is first pasteurized at $90^{\circ} \mathrm{C}$ for 20 seconds and then cooled to $36^{\circ} \mathrm{C}$. After adding $\mathrm{CaCl}_{2}(15-20 \mathrm{~g} / 100 \mathrm{~L}$ of milk), milk was seeded with mixed lactic ferments (Mesophilous: DI-PROX M 229, BioProx, France/Thermophilous: DI-PROX TPM 2, BioProx, France) with $0.03 \%$ of fungal flora (Chr. Hansen Inc., Danemark) of Penicillium camemberti and Geotricum candidum in order to reach the final concentrations of $10^{4} \mathrm{spores} / \mathrm{ml}$ and $2 \times 10^{4}$ spores $/ \mathrm{ml}$, respectively. After the fermentation period of milk $\left(20-25\right.$ minutes at $\left.36^{\circ} \mathrm{C}\right)$, the $\mathrm{pH}$ reached a value of 6.35 , commercial rennet fungal powder Marzyme ${ }^{\mathrm{TM}}$ (standard strength of: 150000 , Danisco. France) was added $(1.5 \mathrm{~g} / 50 \mathrm{Kg}$ of milk), then the coagulum is divided into small cubes $(\varnothing=30 \mathrm{~mm})$. To accelerate draining, the coagulum was stirred twice during 15 minutes with an interval of five minutes. The whey was evacuated by pumping it out, then the moulding was carried out by

Table 1 Distribution of the samples according to the kind of the milk and the ripening stage

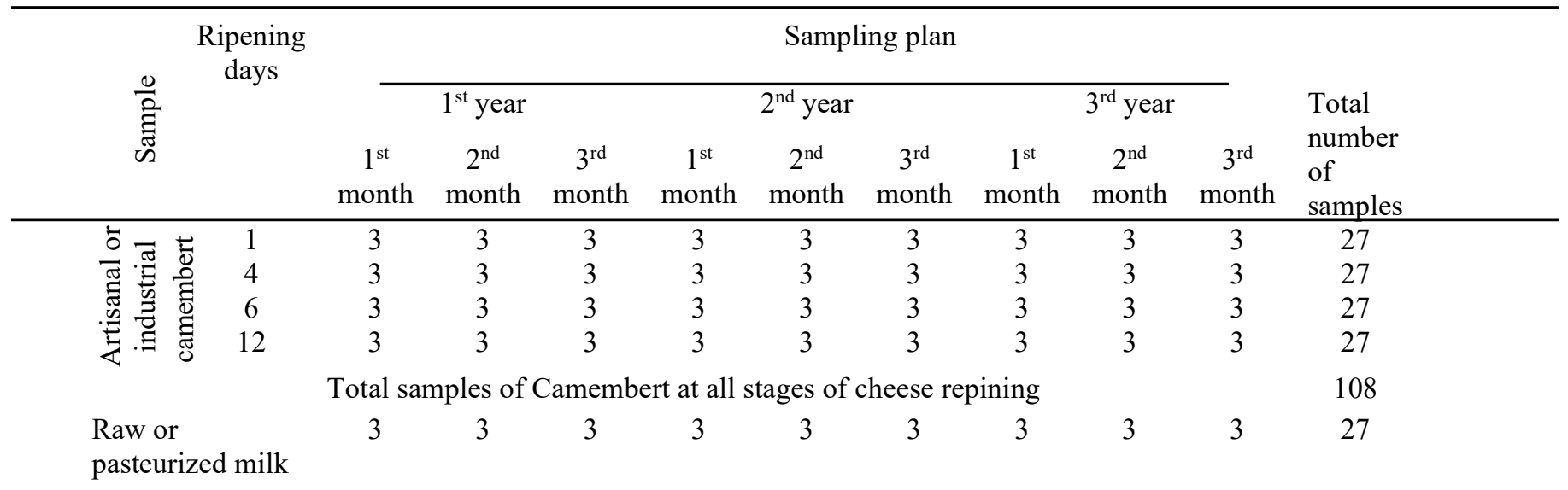


mechanically filling the moulds. The coagulum is drained in polyurethane molds placed on stainless drains during 15 to 20 hours at $\mathrm{RH}$ of 90 to $95 \%\left(27^{\circ} \mathrm{C}-5 \mathrm{~h}\right.$ and $\left.20^{\circ} \mathrm{C}-15 \mathrm{~h}\right)$, with rotations every five hours. After it was removed from the mold, the cheese was salted by brining $(\mathrm{NaCl}=40 \%, \mathrm{pH}=4.5)$ during 30 to 60 minutes at $13{ }^{\circ} \mathrm{C}$. The cheese surface was dried in a draining room during 15 hours $\left(14{ }^{\circ} \mathrm{C}, \mathrm{RH}=85 \%\right)$ with two rotations. Then, it was sprinkled with a suspension of Penicillium camemberti spores $\left(2.10^{9} \mathrm{Spore} / \mathrm{ml}\right)$ (Chr. Hansen Inc., Danemark) and ripened during 12 days $\left(12-13{ }^{\circ} \mathrm{C}, \mathrm{RH}=90-95 \%\right)$ with a rotation every two to three days.

\section{Physicochemical analysis}

Physicochemical parameters during cheese ripening were analysed after removing the cheese crust. Samples of milk were analyzed with Lacto-scan SP (Milkotronic LTD, Bulgaria) for density, fat and proteins). The $\mathrm{pH}$ was measured by immersing the $\mathrm{pH}$-meter glass electrode (Hanna-instrument, Italy) directly in the products (cheeses and milks) (Bouton et al. 1994).The titratable acidity (TA) of the milk was expressed in Dornic degree ( ${ }^{\circ}$ ) (AFNOR, 1980) and as \% of lactic acid for the cheese (Sulieman et al. 2012) The dry-matter (DM) was determined using an infrared desiccator IR35 (Denver instrument, Germany) by evaporation $\left(105^{\circ} \mathrm{C} / 20 \mathrm{~min}\right.$ ) of $3 \mathrm{~g}$ of milk (AFNOR, 1980) or $5 \mathrm{~g}$ of cheese (Randoin and Jourdan ,1952). The Fat content of cheese was determined by Van-Gulik butyrometer (Funkgerber Instrument, Germany) (JORADP, 2014).

\section{Protein fractionation}

Protein concentration was determined using the Lowry protein procedure at $750 \mathrm{~nm}$ with Folin-Ciocalteu's phenol reagent (Lowry

Table 2 Milk and cheese microbial flora enumerated during ripening

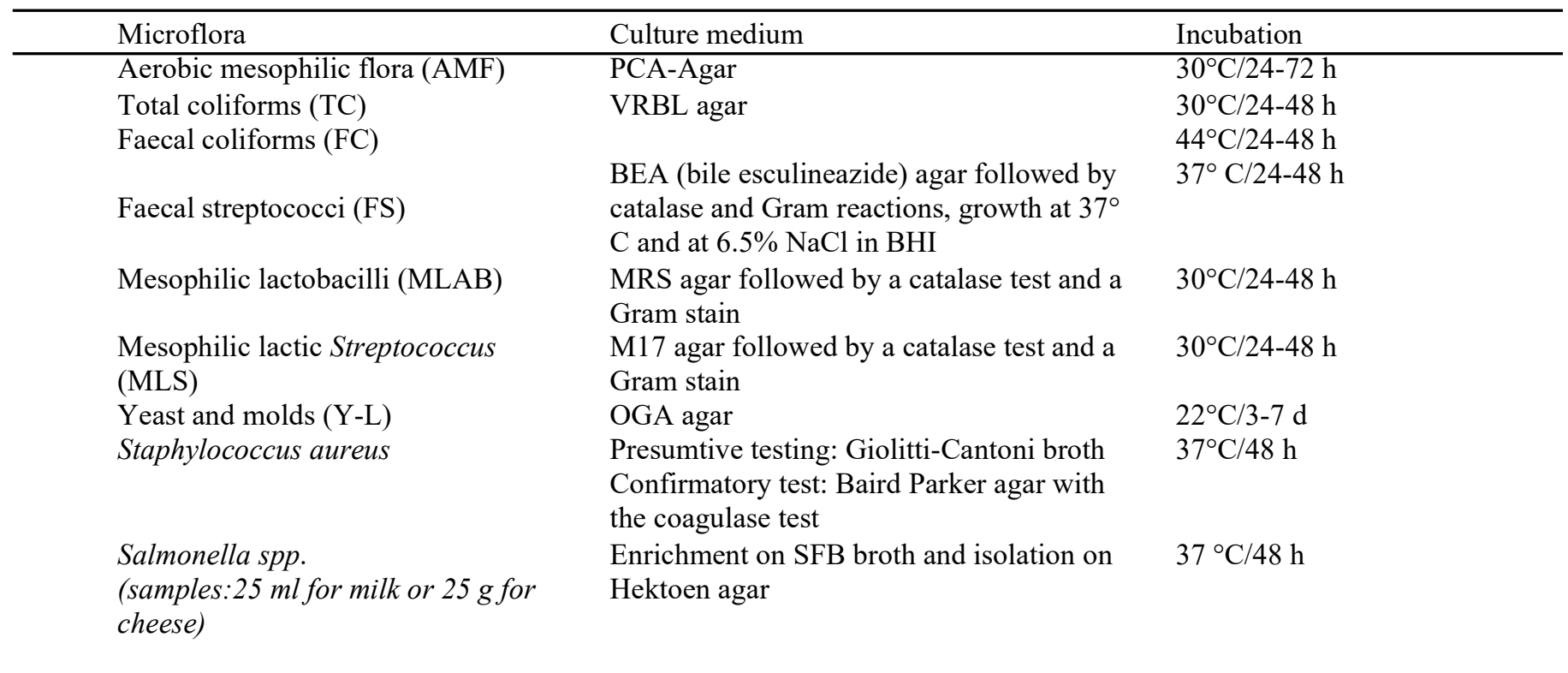

et al. 1951). Bovine Serum Albumin was used as a standard. From slurry prepared from by mixing $20 \mathrm{~g}$ of cheese (crust removed and crushed) in $40 \mathrm{ml}$ of sodium citrate buffer $(0.5 \mathrm{M}, \mathrm{pH} 7)$, three protein fractions, which are the total protein content (TP), the acid soluble protein (ASP) and the non-protein nitrogen (NPN), were obtained by combining the methods reported by Gripon et al. (1975) and Guerra-Martinez et al. (2012).

\section{Free amino acids}

Total levels of free amino acids (FAA) in the pH4.6-Soluble fractions of the cheese were determined by the 2, 4, 6, trinitrobenzene-1-sulfonic acid (TNBS) method described by Polychroniadou (1988) modified by Bouton et al. (1993). Cheese extracts were prepared, as mentioned above. The use of a range of glycine standard (0.01-0.5 mM) allowed expressing the measurements in $\mathrm{mEq}$ glycine/g of protein.

\section{SDS-polyacrylamide gel electrophoresis (SDS-PAGE)}

Proteolysis during cheese ripening from the water-soluble proteins (WSP) and insoluble protein fractions at $\mathrm{pH} 4.6$ was evaluated by SDS-PAGE (Barac et al. 2016). The fractions were prepared according to the techniques reported by Dupas et al. (2009).The PAGE-SDS was performed according the method described by Laemmli (1970). A marker kit was for bovine serum albumin (67 kDa), ovalbumin (45 kDa), $\beta$-Lactoglobulin $(18 \mathrm{kDa})$ and $\alpha$-Lactalbumin (14 kDa).

\section{Reversed-phase high performance liquid chromatography (RP-} HPLC) of the cheese solutions water-soluble fractions

The proteolysis during cheese repining was also assessed by RP-HPLC. Samples of WSP $(3 \mathrm{mg} / \mathrm{ml})$ were prepared in a Bis-Tris 
buffer with a $\mathrm{pH} 8$ and filtred through $0.45 \mu \mathrm{m}$ nylon filters (Sartorius, Germany). Twenty $\mu 1$ of filtrate was injected in a Lichrosorb C8 column $(5 \mu \mathrm{m}, 125 \mathrm{x} 4,1 \mathrm{~mm})$. The mobile phase was constituted by a solvent A $(10 \%$ acetonitrile, $0.1 \%$ trifluoroacetique acid: TFA) and a solvent B (60\% acetonitrile, $0.02 \%$ TFA). The elution was performed using a $0-50 \%$ binary gradient of the solvent B during 50 minutes with a flow rate of 0.2 $\mathrm{ml} / \mathrm{min}$ at $35^{\circ} \mathrm{C}$. The detection was performed under $\mathrm{UV}$ at 214 $\mathrm{nm}$.

\section{Lipolysis}

The lipolysis was assessed by measuring the amount of free fatty acids (FFA $)$ according to the method described by Deeth et al. (1975). The FFAs were expressed in equivalent of oleic acid per $100 \mathrm{~g}$ of fat, referring to a standard curve of oleic acid (0.10-10 $\mathrm{mg} / \mathrm{ml})$.

\section{Microbiological analysis}

Milk and cheese microflora during ripening were determined by the conventional techniques for which the incubation conditions and the medium used are reported in Table 2. Cheese samples were collected at 1,6 and 12 days of repining. The dilutions were prepared either directly from milk or from cheese prepared according the method described by Lenoir (1963) after some modifications. After removing the crust, $10 \mathrm{~g}$ samples of cheese were homogenized in a Stomacher 400 (Seward Medical, Londres, UK) with $90 \mathrm{ml}$ of sterile sodium citrate $(2 \%)$ at $40{ }^{\circ} \mathrm{C}$. Decimal dilutions of milk and cheese solution were prepared with Ringer's solution. Germ counts were expressed according to the formula of Joffin and Joffin (1999).

\section{Anti-microbial activity of water-soluble extract}

The raw water-soluble extracts (WSE) were extracted at the $12^{\text {th }}$ day of cheese ripening, as mentioned above (fractionation of WSP), without acidification. In order to eliminate the antagonistic effects of the $\mathrm{pH}$ and $\mathrm{H}_{2} \mathrm{O}_{2}$, the WSE was neutralized to $\mathrm{pH} 6.8$ with $\mathrm{NaOH}(2 \mathrm{~N})$ and after addition of few drops of catalase (1 $\mathrm{mg} / \mathrm{ml}$ ), it was incubated for one hour at $30{ }^{\circ} \mathrm{C}$ (Sahraoui et al. 2015). The raw WSE and the neutralized WSE were filtered through $0.22 \mu \mathrm{m}$ filters .The agar-disc diffusion assay was performed according to protocol reported by Motta and Brandelli (2002).

Table 3 Physicochemical compositions of the milk
The antibacterial activity was tested against Escherichia coli ATTCC 25922 and Staphylococcus aureus ATTCC 25923. All the strains were standardized by spectrometry $(620 \mathrm{~nm})$ at an optical density (OD) of 0.08-01, according to the Antibiogram Committee CASFM/EUCAST (2019).

Aliquots of $20 \mu \mathrm{l}$ were applied on five discs $(6 \mathrm{~mm})$ : two discs of the raw WSE, two discs of neutralized WSE and one disc with broth (as negative control). The Petri dishes were placed in a refrigerator at $4{ }^{\circ} \mathrm{C}$ for two hours. The antimicrobial effect of WSE (expressed in $\mathrm{mm}$ ) was examined after incubation for 24 hours under appropriate culture conditions. Three replicates were performed on different dates.

\section{Statistical analysis}

The physicochemical composition and microbiological counts, between raw milk and pasteurized milk, were assessed by the Student's t-test (5\% level of significance). An Analysis of variance (ANOVA), using the Tukey test for pair wise comparison of means, was performed (significant level of $5 \%$ ), to follow the changes in the physicochemical and microbiological parameters during cheese ripening. A principal component analysis (PCA) was run in order to analyze the effect of the ripening stage on the physicochemical and microbiological interactions during cheese maturation. The statistical analyses were performed using STATbox software ver. 6.4.

\section{Results and Discussion}

\section{Physicochemical characteristics of milk}

The milk physicochemical characteristics are reported in Table 3. Among the analyzed parameters, significant difference was only found between the DM and milk TP $(\mathrm{P}<0.05)$. The sampling season can affect the physico-chemical and microbiological quality of milk (Spike and Freeman, 1967; Nalepa et al. 2018). The effect of seasonality was discarded in this study, as sampling occurred during the same periods of the year.

\section{Changes in physicochemical parameters during ripening}

The statistical analyses of the physicochemical parameters (Table 4) showed significant differences $(P<0.05)$ depending on the stage of ripening and the type of cheese.

\begin{tabular}{llc}
\hline Composition & Raw milk & Pasteurized milk \\
\hline pH & $6.69^{\mathrm{a}} \pm 0.02$ & $6.66^{\mathrm{a}} \pm 0.06$ \\
TA $\left({ }^{\circ} \mathrm{D}\right)$ & $17^{\mathrm{a}} \pm 0.93$ & $15.66^{\mathrm{a}} \pm 0.41$ \\
Densité & $1.03^{\mathrm{a}} \pm 0.01$ & $1.027^{\mathrm{a}} \pm 0.7$ \\
$\mathrm{DM}(\mathrm{g} / \mathrm{l})$ & $122.1^{\mathrm{b}} \pm 0.3082$ & $108.13^{\mathrm{a}} \pm 2.31$ \\
FAT $(\mathrm{g} / \mathrm{l})$ & $33.66^{\mathrm{a}} \pm 2.16$ & $36^{\mathrm{a}} \pm 0.61$ \\
TP $(\mathrm{g} / \mathrm{l})$ & $29.45^{\mathrm{b}} \pm 0.09$ & $26.66^{\mathrm{a}} \pm 0.41$ \\
\hline
\end{tabular}

Results in the same column for the same parameter with different superscripts are significantly different at $\mathrm{P}<0.05$. 
The $\mathrm{pH}$ is negatively correlated with titratable acidity between the different cheese types and the ripening stages. From the first to the twelfth day of ripening, the $\mathrm{pH}$ values increased from 4.59 and 4.67 (IC) to 5.13 and 5.36, respectively. This is due to the deacidification of the cheese, which is better assessed through measuring the titratable acidity. Indeed, cheese acidity decreased between the first day $(9.59 \%$ for the artisanal cheese and $9.11 \%$ for the industrial) and the last dayof ripening (5.83\% artisanal cheese and $6.17 \%$ for the industrial)

In the case of Camembert the neutralization and deacidification of cheese is due to the assimilation of lactic acid and the releasing of $\mathrm{NH}_{3}$ by the fungal flora, especially Penicillium camemberti and Geotichum candidum, which promoted the action of proteolytic enzymes and increased the proteolysis index (ASP\%, NPN\%, and FAA) (Leclercq-Perlat et al. 2004).

Dry Matter increased during ripening with significant differences between the stages and the cheese types. The values range from $39.40 \%$ (AC) and $40.89 \%$ (IC) at the first day, to $50.09 \%$ (AC) and $49.51 \%$ (IC) at the $12^{\text {th }}$ day of ripening. These findings may be attributed to the dehydration during cheese repining. This phenomenon is caused by water loss and exchanges in volatile compounds (ammoniac, fat volatile fatty acids, etc.) between the cheese surface and the ripening room environment (Bertolino et al. 2011). The dehydration of cheese affects the contents of DM, fat and protein during ripening process. Indeed, at the last ripening day, the fat content reached at $25.99 \%$ for the $\mathrm{AC}$ and
$28.75 \%$ for the IC and the protein contents attained $15.25 \%$ for the $\mathrm{AC}$ and $17.20 \%$ for the IC.

\section{Progress of proteolysis and lipolysis during ripening}

The proteolysis index, ASP/TP (ASP \%) and NPN/TP (NPN \%) ratios, have been used by many authors as cheese ripening indicators in order to estimate the degree of the proteolysis (Leclercq-Perlat, 2000). Statistical analysis showed significant differences between the types of cheeses and stages of ripening. $\mathrm{ASP} \%$ increased from the first to the twelfth day of ripening, with the following values respectively: $5.22 \%$ to $22.24 \%$ for AC and from $4.69 \%$ to $17.44 \%$ for IC. The non-protein nitrogen values also increased from $0.310 \%$ to $0.44 \%$ for $\mathrm{AC}$ and from $0.22 \%$ to $0.28 \%$ for IC. The results of the free amino acids contents during cheese repining, revealed significant differences $(\mathrm{P}<0.05)$ between the cheeses. Free fatty acids increased from 0.12 (first day) to 0.25 ( $12^{\text {th }}$ day) for AC and from 0.09 (first day) to 0.23 ( $12^{\text {th }}$ day) for IC. The combined effect of the microflora and indigenous enzymes of the raw milk explains the high degree of the proteolysis in AC. The action of intracellular enzymes, released during cell lysis, on the proteolysis of the cheese caseins has been reported by Saboya et al. (2001). The heat treatment of milk slows down cheese proteolysis by modifying the total flora and the proteolysis system during cheese ripening, such as the Camembert (Samelis et al. 2009). The proteolysis activity of the plasmin in ripened cheeses depends on the technology applied in milk processing. The effect of plasmin on caseins of cheese made from pasteurized

Table 4 Changes in physicochemical parameters during ripening of artisanal and industrial cheeses

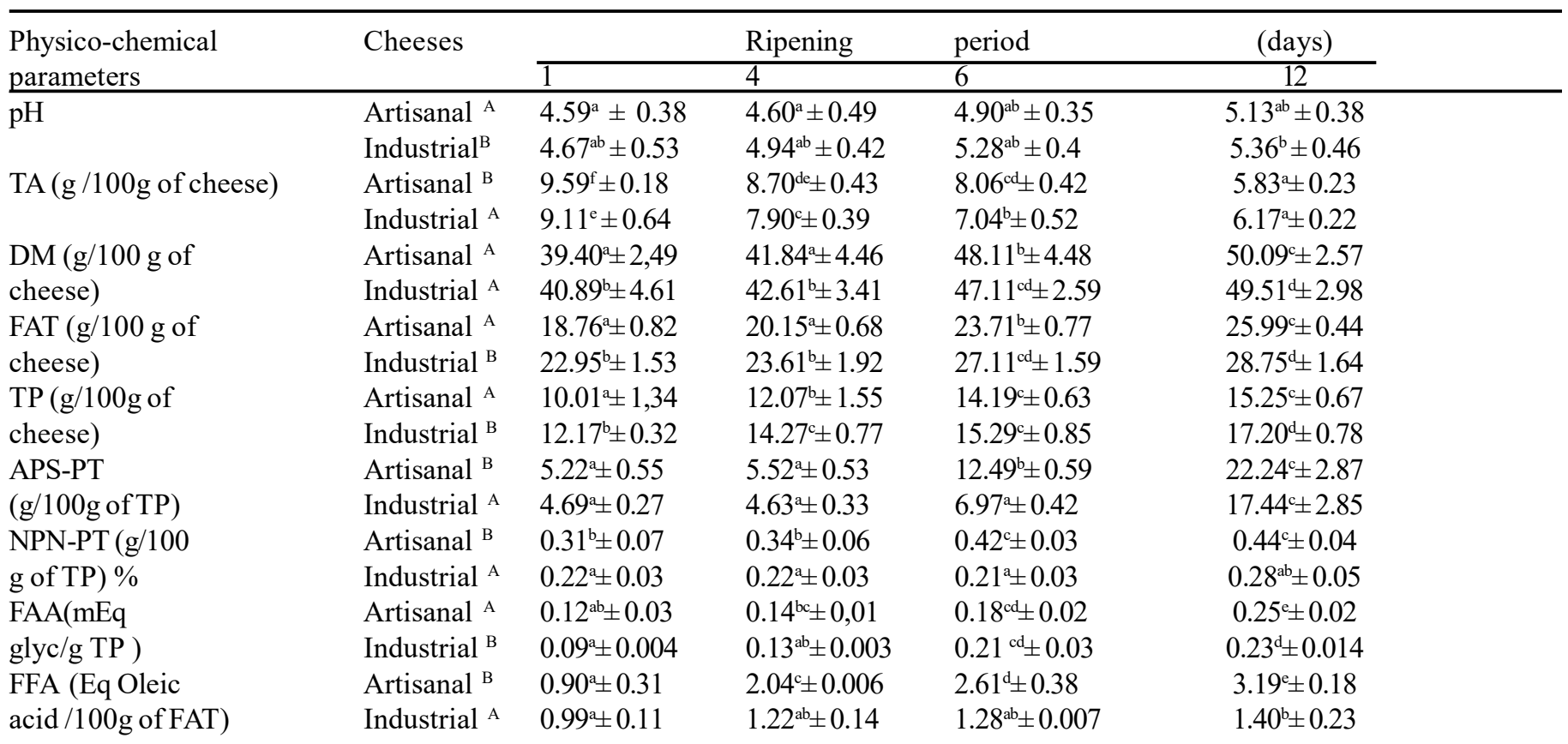

Results in the same row or column for the same parameter with different superscripts (in upper case or lower case) are significantly different at $\mathrm{P}<0.05$ 
Fig. 1 RP-HPLC water soluble peptide (WSP) fractions from AC and IC at different periods of cheese repining ( $1,6 \mathrm{~d}$ and 12 days)
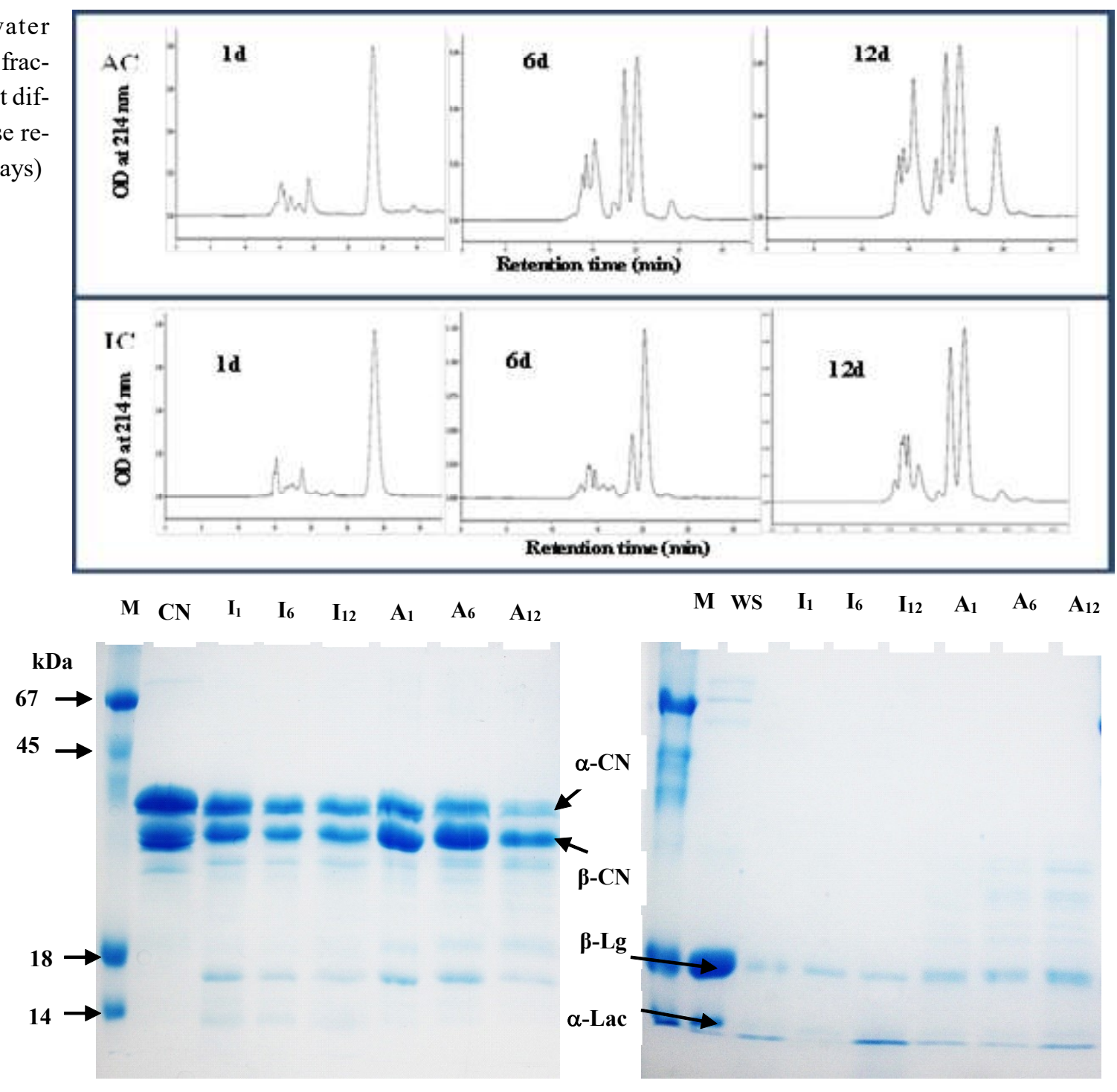

a

Fig. 2 SDS-PAGE electrophoretic profiles of the insoluble (a) and WSP (b) fractions at $\mathrm{pH} 4.6$ of AC and IC at different days of repining (1, 6 and 12 days)

milk, decreases significantly with increasing temperatures (Benfeldt et al. 1997; Buffa et al. 2000). The action of the rennet, the plasmin, the proteases and the microbial peptidases on the caseins throughout ripening releases peptides and amino acids, which increases the ripening index: ASP\%, NPN\% and FAA \% (Gonzalez et al. 2003; Upreti et al. 2006; Orlyukand Stepanishchev, 2014).

Free fatty acids during cheese ripening, increase as does the proteolysis and the fat content. Similar results have been reported by Batool et al. (2018). FFA presents significant differences between the stages and the types of cheeses. The high level of FFA in the AC can be explained by the micro floral composition of raw milk and the lipoprotein lipase activities. Indeed, the negative effect of pasteurization on LPL activities and the highest of lipolysis degrees in cheeses made from raw milk compared to those made from pasteurized milk have been reported by several authors (McSweeney et al. 1993; Franco et al. 2001).

\section{RP-HPLC profiles}

The RP-HPLC profiles of WSP of the two cheeses, showed an increase in the number of peaks during the ripening process (Figure 1). These peaks were more frequent in AC than in IC. This is due to the high level of proteolysis in $\mathrm{AC}$, the proteolysis activity of the indigenous milk enzymes, the microbial enzymes 
as well as the activity of the residual rennet. The heat treatment has a negative effect on the proteolysis process during cheese repining. Benfeldt and Sorensen (2001) showed an inverse relationship, during cheese ripening, between the temperature of heat treatment of milk and the proteolysis as followed by an RPHPLC. According to Trujillo et al. (1997) and Van Hekken et al. (2007), most of the peptides which are released during ripening, are generated from the caseins hydrolysis by rennet and plasmin with a molecular weight ranging from 10 to $20 \mathrm{kDa}$.

\section{Electrophoresis of WSP and insoluble proteins fractions}

The figure 2 , shows that the indigenous casein migrates as two main bands corresponding to $\alpha s-\mathrm{CN}$ and $\beta-\mathrm{CN}$. The band intensity decreased throughout ripening, leaving two news bands of low molecular weight (Figure 2 ${ }_{\mathrm{b}}$ ).

This trend was most pronounced for $\mathrm{AC}$ at the $12^{\text {th }}$ day of ripening. These profiles revealed that the caseins proteolysis changes over time and with the type of the cheese, with higher as-CN proteolytic rates than with $\beta-\mathrm{CN}$. Indeed, new bands with lower molecular weight and the increase in peaks of WSP obtained with RP-HPLC, explain the higher proteolysis index and the free amino acids rates observed in AC than in IC. Our findings are consistent with those reported by Gobbetti et al. (2002), who noted that chymosin hydrolyzes easily $\alpha \mathrm{s}_{1}-\mathrm{CN}$ than $\beta-\mathrm{CN}$, releasing a peptide identified as $\alpha_{s 1}$-I-casein $\mathrm{f}(24-199)$. Chymosin is also able to hydrolyze $\beta-C N$ (Addeo et al. 1980). The main cleavage site of chymosin in $\beta-\mathrm{CN}$ is Leu ${ }^{192}-\mathrm{Tyr}^{193}$. However, in pure solution, it can hydrolyze $\beta-\mathrm{CN}$ at seven sites, generating f1-192, fl-189, f1-163/4/5 et f1-139 peptides, which are called $-\beta-\mathrm{I}^{\mathrm{I}}$, $-\beta-\mathrm{I}^{\mathrm{II}},-\beta-\mathrm{II}$ and $-\beta$-III respectively (Visser, 1993). Orlyuk and Stepanishvhev (2014) reported that between the first and the 21 st days of the Camembert ripening, the content of $\alpha s-\mathrm{CN}$ and $\beta$-CN decreased respectively, by $53 \%$ and $25 \%$. Proteolysis during the Camembert ripening is mainly due to the action of five proteinases: rennet (chymosin and pepsin), plasmin, aspartyl and methaloprotease of Penicillium caseicolum. However, the rennet seems to be inactive on $\beta-\mathrm{CN}$, but acts early on $\alpha \mathrm{s}_{1}-\mathrm{CN}$ with a similar action to that of aspartyl-proteinase on $\alpha \mathrm{s}_{1}-\mathrm{CN}$. On the contrary, the action of the plasmine on $\beta-\mathrm{CN}$ is observed at the $21^{\text {st }}$ day, while the proteolysis of $\beta-\mathrm{CN}$ by the aspartyl and by the methaloproteases is detectable after seven and ten days of ripening respectively (Mane and McSweeney, 2019).

\section{Growth of microflora during ripening}

The results of milk microorganism counts are reported in table 5 .The samples comply with the standards described in the Official Journal of the People's Democratic Republic of Algeria ${ }^{\circ} 39$ of July 2017 (JORADP, 2017).The tests to detect pathogens in the milks and the cheeses, especially for Staphylococcus aureus and Salmonella, were negative. The number of microorganisms is significantly higher in the raw milk than in the pasteurized. This reflects the lethal effect of the pasteurization on milk microflora.

The results of the microflora evolution during ripening show an inverse relationship between two microbial groups (Figure 3). The group a, including faecal streptococci and faecal and total coliforms, decreased gradually during ripening. The group $b$, which consists of total aerobic mesophilic flora, streptococci, Lactobacillus, yeast and molds, increased during the ripening process. The trends were similar for both studied cheeses. The differences were rather concerned with variations in the number and in the distribution of the microflora. Indeed, the growth of the microflora during ripening of $\mathrm{AC}$ recorded significant differences between the first and the twelfth days for AMF ( $7.41 \pm 0.35 \mathrm{log} \mathrm{cfu} / \mathrm{g}$ and $9.35 \pm 0.31 \mathrm{log}$ cfu/g respectively), MLAB (4.41 $\pm 0.23 \mathrm{log} \mathrm{cfu} / \mathrm{g}$ and $5.98 \pm 0.49 \mathrm{log} \mathrm{cfu} / \mathrm{g}$ respectively), FC (1.60 $\pm 0.0810 \mathrm{~g} \mathrm{cfu} / \mathrm{g}$ and $0.331 \pm 0.41 \mathrm{og} \mathrm{cfu} / \mathrm{g}$ respectively) and FS $(1.33 \pm 0.2 \log \mathrm{cfu} / \mathrm{g}$ and $0.58 \pm 0.15 \mathrm{log} \mathrm{cfu} / \mathrm{g}$ respectively). However, IC recorded a slight contamination of TC from the beginning until the sixth day of ripening then it dropped drastically at the twelfth day. With regard to fecal coliform, it disappeared from the sixth day of ripening stage of IC.

The decrease of contamination and the pathogen microflora, during the ripening process of cheese raw milk, is due to the increase in the ripening microflora, which modifies the physicochemical parameters $\left(\mathrm{a}_{\mathrm{w}}\right.$ and $\left.\mathrm{pH}\right)$ and releases peptides with antibacterial activity (Fontan et al. 2001; Arenas et al. 2004; Kirdar et al. 2018). However, some studies demonstrated that coliforms decrease during the first week and then increase till the end of the ripening process, with higher rates for the Camembert made

Table 5 Microbiological count in milk

\begin{tabular}{llc}
\hline Microflora $\left(\log _{10}\right.$ CFU/mL) & Raw milk & Pasteurized milk \\
\hline Aerobic mesophilic flora (AMF) & $4.99^{\mathrm{b}} \pm 0.306$ & $3.71^{\mathrm{a}} \pm 0.42$ \\
Total coliforms (TC) & $1.66^{\mathrm{b}} \pm 0.11$ & $0.32^{\mathrm{a}} \pm 0.24$ \\
Faecal coliforms (FC) & $0.19^{\mathrm{b}} \pm 0.17$ & $0.0033^{\mathrm{a}} \pm 0.004$ \\
Faecal streptococci (FS) & 0 & 0 \\
Mesophilic lactobacilli (MLAB) & $3.63^{\mathrm{b}} \pm 0.46$ & $0.96^{\mathrm{a}} \pm 0.178$ \\
Mesophilic lactic streptococcus (MLS) & $2.49^{\mathrm{b}} \pm 0.22$ & $0.4^{\mathrm{a}} \pm 0.14$ \\
Yeast and molds (Y and M) & $1.57^{\mathrm{b}} \pm 0.19$ & $0.15^{\mathrm{a}} \pm 0.19$ \\
\hline
\end{tabular}

Results in the same column for the same parameter with different letters are significantly different at $\mathrm{P}<0.05$ 
Fig. 3 Microflora evolution in the cheeses during ripening

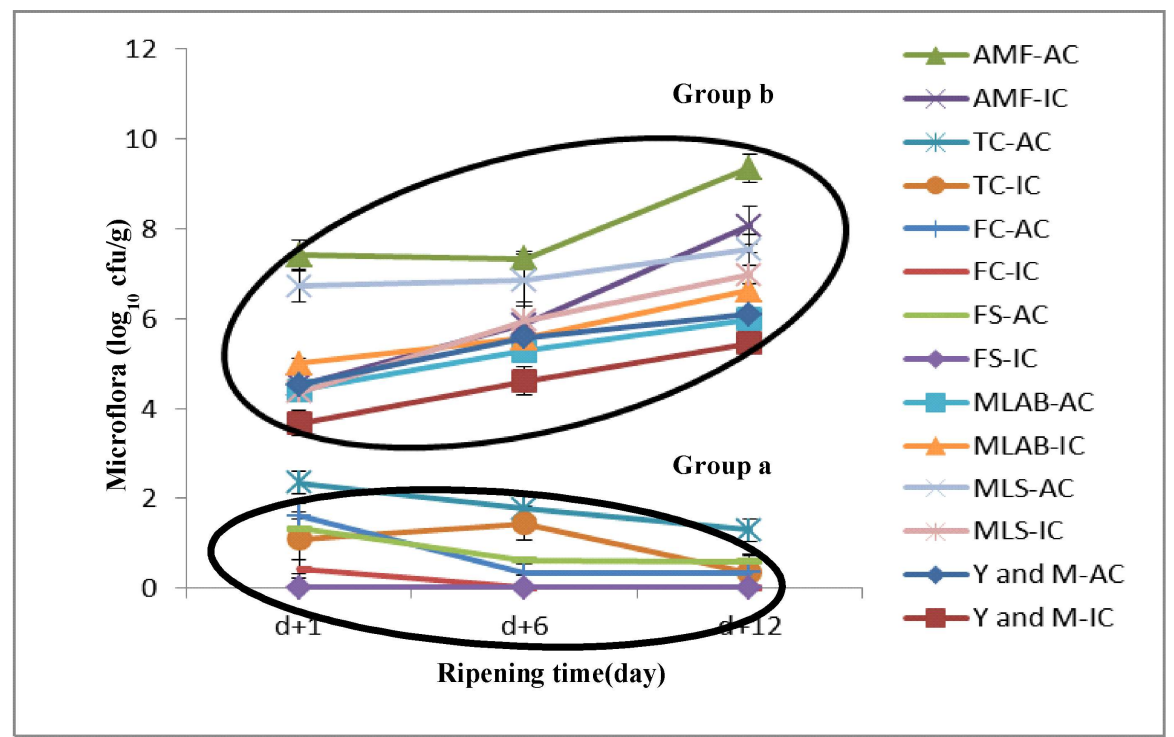

Legend: Artisanal Camembert (AC), Industrial Camembert (IC). Group a: Contamining flora (Total coliforms (TC), Faecal coliforms (FC), Faecal streptococci (FS)). Group b: Ripening flora (Aerobic mesophilic flora (AMF), Mesophilic lactobacilli (MLAB), Mesophilic lactic streptococcus (MLS), Yeast and molds (Y and M)).

Table 6 Antibacterial activity statistics for the raw and neutralized supernatants

\begin{tabular}{llcc}
\hline \multirow{2}{*}{ Strains } & Supernatants & $\begin{array}{c}\text { Cheeses } \\
\text { type }\end{array}$ & $\begin{array}{c}\text { Inhibition zone } \\
\text { diameter } \\
(\mathrm{mm}) \\
\text { Mean } \pm \text { SD }\end{array}$ \\
\hline & Raw & IC & $10.8 \pm 0.97$ \\
Staphylococcus aureus & ATCC 25923 & AC & $10.5 \pm 0.98$ \\
& Neutralized & IC & $10 \pm 1.94$ \\
& & AC & $8.8 \pm 0.32$ \\
& Raw & IC & $11.7 \pm 0.21$ \\
& & AC & $11.3 \pm 0.21$ \\
& Neutralized & IC & $8.2 \pm 0.64$ \\
& & AC & $7.9 \pm 0.32$ \\
\hline
\end{tabular}

from raw milk than for those made from pasteurized milk (Mourgues et al. 1977; Rutzinski et al. 1979).

\section{Antimicrobial activity analysis}

The results of the analysis of the supernatant antimicrobial activity are reported in the Table 6 . The presence of inhibition zones after neutralization of the supernatants suggests that the antibacterial effect could only be due to the presence of antibacterial substances, such as bacteriocins and bioactive peptides (Ortolani et al. 2010; Corrêa et al. 2011).

Cheese protection against pathogens proliferation can be performed by the indigenous antimicrobial agents of milk, such as lactoferrin (Farnaud and Evans, 2003), lactoperoxydase system (LPS) (Seifu et al. 2005) and lysozyme (Claeys et al. 2013). These agents are inactivated by the heat treatment (Conesa et al. 2010;
Dumitraşcu et al. 2012; Claeys et al. 2013). These results explain in large part the decrease in the contaminating microflora during the ripening of $\mathrm{AC}$ and the role of the lactic microflora of the raw milk during the cheese ripening, thanks to their proteolytic activity and the production of bacteriocins.

Most of known varieties of cheeses contain a certain amount of kappacins (A and B) in form of caseinomacropeptide, with an antimicrobial activity, which are released as a result of the action of coagulant enzymes (rennet or other coagulant enzymes) on the $\kappa$-casein (Vajiheh, 2012). In the case of the Camembert, many studies demonstrated the effect of lactic bacteria and their products on the inhibition of Listeria ssp during cheese ripening (Wan et al. 1997). Lignitto et al. (2012) and Nguyen Thi et al. (2013) reported that inhibition of Listeria monocytogenes and Listeria innocua by water soluble extracts of cheese made from raw milk is attributed to peptides with $\mathrm{MW}<1 \mathrm{kDa}$ and to the 


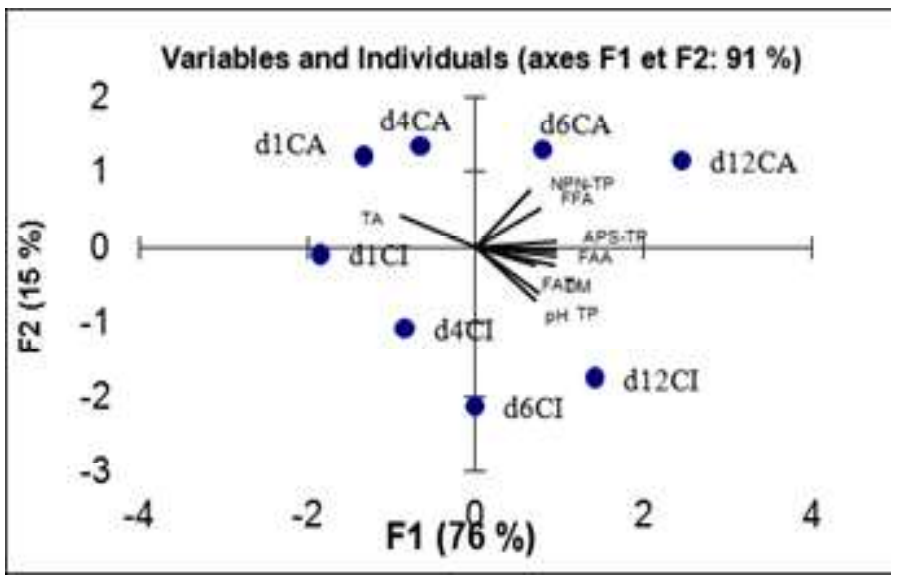

Fig. 4 Factorial plane 1-2 of the component analysis for the physicochemical changes during cheese repining

antimicrobial peptides $\alpha s_{1}-\mathrm{CN} f(1-23)$ et $\alpha s_{2}-C N f(183-207)$. The antimicrobial activity of the cheese water-soluble extracts could not only be attributed to the known intact bacteriocins with MW $>3 \mathrm{kDa}$, but also for the fraction with $\mathrm{MW}>10 \mathrm{kDa}$ (Drider et al. 2006; Pritchard et al. 2010). During the ripening process of the Camembert, 15 peaks-RPHPLC were identified as potentially bioactive, all stemming from $\beta-\mathrm{CN}$ with predominance of antibacterial fragments $\beta-\mathrm{CN}$ f(193-209) (Galli et al. 2019).

\section{Interactions among the physicochemical and microbiological parameters and their progress during ripening}

A PCA was run to analyze the interactions between the physicochemical and microbiological parameters and their evolution during ripening. The results related to physicochemical parameters during cheese repining are presented in Figure 4.

The first two axes explain 91\% of the total variance. Axis F1 represents the maturity (temporal) gradient during the ripening process. F2 represents the type of the product. The projection of the means obtained from the three years of study from the same stage of ripening shows that $\mathrm{F} 1$ opposes the artisanal Camembert to the industrial. The small distance between $\mathrm{d} 1 \mathrm{AC}$ and $\mathrm{d} 4 \mathrm{AC}$ shows the high correlation (low changes) registered between the two first considered ripening stages of AC. In contrast, the temporal gradient revealed great changes (lower correlations) from the second stage of ripening, expressed here by an increase in the distance between successive stages (d4AC, d6AC, and d12AC). At the same stages, these differences were less pronounced during IC ripening, which registered an appreciable change only between the two last stages (J6IC and J12IC). The degree of maturation of $\mathrm{AC}$ is the result of the combined effects related to the production conditions and the physicochemical and microbiological proprieties of the raw milk. Consequently, IC is richer in DM, fat and proteins, but less matured than AC. Moreover, the factorial plane 1-2 highlights the concentration of

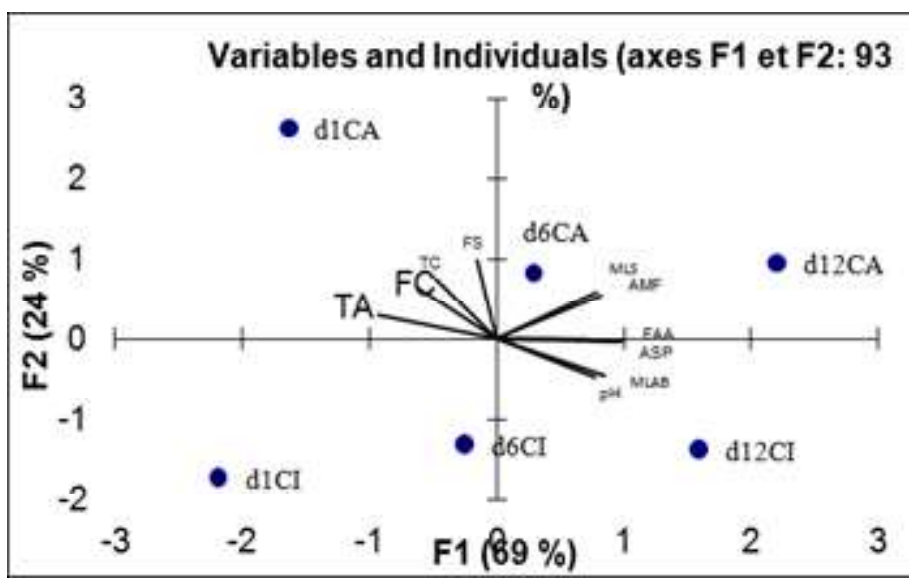

Fig. 5 Factorial plane 1-2 of the component analysis for the physicochemical and microbiological parameters interactions during ripening

the points representing fat, DM and proteins close to the last stage of ripening for $\mathrm{IC}$, while the points representing the maturation index (ASP, NPN, FAA and FFA) are gathered towards this final ripening stage of $\mathrm{AC}$.

The results of the component analysis for the physicochemical and microbiological parameters interactions during ripening are presented in Figure 5.

The axes F1 and F2 expressed $69 \%$ and $24 \%$ of the total variance respectively. The change in the physicochemical parameters is opposed to the contaminating microorganisms. F2 opposes the coliforms (faecal and total), the faecal streptococci to the mesophilic lactic bacteria (Streptococci and Lactobacillus), the MFAT, molds and yeasts. This axis also opposes contaminating germs to $\mathrm{pH}, \mathrm{FAA}$ and ASP.

A scan of figures 4 and 5 explains the decrease of pathogenic organisms during ripening of the artisanal cheese. This could be due to the action of indigenous enzymes of the raw milk and increase in of lactic bacteria and the fungal flora, which lead to the release of bioactive peptides, with antibacterial effects by their proteolytic action, and production of bacteriocins by lactic bacteria. These results are confirmed by the correlation matrix obtained between the physicochemical and microbiological parameters, which revealed that molds and yeasts have an impact on the proteolysis, with significant $(\mathrm{P}<0,05)$ positive correlations with the proteolysis products of ASP $(r=0.88)$ and FAA $(r=$ 0.90). MLAB showed significant negative correlations with the pathogenic organisms TC $(r=-0.87), F C(r=-0.84)$ and FS $(r=$ 0.86). This explains the effect of MLAB on the decrease of these pathogenic germs during ripening of the cheeses made from raw milk and the role of lactic microflora in their bio-conservation. 


\section{Conclusions}

The physicochemical parameters showed the same trends and recorded higher values in the Camembert made from raw milk. The inhibition of Escherichia coli and Staphylococcus aureus by the neutralized water-soluble fractions revealed the effect of the bioconservation of the camembert made from raw milk by an eventual presence, in the cheese, of bacteriocins and bioactive peptides with antibacterial effect. The current study opens up new perspectives within the framework of the dairy industry in Algeria, encouraging stockbreeders and farmers to transform the raw milk into healthy dairy products and provide steady and more active incomes than those generated from selling milk to collectors.

\section{Acknowledgements}

We would like to thank Dr Said Slimani, who read through the text, for his suggestions regarding the English and we also would like to thank Miss Lamia Bouadjela and Zobiri Assia for their technical assistance, from university Mouloud Mammeri TiziOuzou (Algeria).

\section{References}

Addeo F, Pelissier JP, Chianes AL (1980) Specific action of milk-clotting enzymes on water buffalo caseins. I. Effect of chymosin on $\beta$ casein. J Dairy Res 47:421-426. doi:10.1017/S0022029900021324

AFNOR (Association Française de Normalisation) (1980) Lait. Détermination de la matière sèche. NF V04 207.In : AFNOR (Ed.), Recueil de normes françaises. Laits et produits laitiers. Méthodes d'analyse. Paris : Normalisation française, 33-34

Aissaoui ZO, Benatallah L, El Hannachi G, Zidoune MN (2011) Manufacture and characteristics of the traditional Algerian ripened bouhezza cheese. J Food Agric Enviro 9: 69-100

Arenas R, Gonzalez L, Bernardo A, Fresno JM, Tornadijo ME (2004) Microbiological and physico-chemical changes in Genestoso cheese, a Spanish acid curd variety, throughout ripening. Food Control 15: 271-279. doi:10.1016/S0956-7135(03)00067-7

Barac M, Smiljanic M, Žilic S, Pesic M, Stanojevic S, Vasic, M, Vucic T, Kostic A (2016). Protein profiles and total antioxidant capacity of water soluble and insoluble protein fractions of white cow cheese at different stage of ripening. Mljekarstvo 66: 187-197.doi: 10.15567/ mljekarstvo.2016.0303

Batool M, Nadeem M, Imran M, Imran TT, Jalees AB, Ayaz M (2018) Lipolysis and antioxidant properties of cow and buffalo cheddar cheese in accelerated ripening. Lipids Health Dis 17: 110.doi:10.1186/s12944-018-0871

Benfeldt C, Sorensen J, Katrine H, Petersen E, Petersen T (1997) Heat treatment of cheese milk: Effect on plasmin activity and proteolysis during cheese ripening. Int Dairy J 7: 723-731. doi: 10.1016/S09586946(97)00083-6

Benfeldt C, Sorensen J (2001) Heat treatment of cheese milk: effect on proteolysis during cheese ripening. Int Dairy J 11: 567-574. doi :10.1016/S0958-6946(01)00078-4

Bertolino M, Dolci P, Giordano M, Rolle L, Zeppa G (2011) Evolution of chemico-physical characteristics during manufacture and ripening of Castelmagno PDO cheese in wintertime. Food Chem 129: 10011011. doi:10.1016/j.foodchem.2011.05.060
Bouton Y, Guyot P, Dasen A, Grappin R (1993) Activité protéolytique de souches de lactobacilles thermophiles isolées de levains et de Comté : I. Validation sur mini fromages des techniques de laboratoire. Le Lait 73: 265-279. doi: 10.1051/lait: 1993325

Bouton Y, Guyot P, Dasen A, Grappin R (1994) Activité protéolytique de souches de lactobacilles thermophiles isolées de levains et de Comté : I I .Application en sites industriels. Le Lait 74: 33-46. doi: 10.1051/ lait: 199414

Buffa M, Trujillo AJ, Roy C, Guamis B (2000) Changes in chemical and microbiological characteristics of goat cheese made from raw, pasteurized or high-pressure-treated milk. High Pressure Res 19: 27-32. doi :10.1080/08957950008202531

Claeys WL, Cardoen S, Daube G, De Block J, Dewettinck K, Dierick K, De Zutter L, Huyghebaert A, Imberechts H, Thiange P, Vandenplas Y, Herman L (2013) Raw or heated cow milk consumption: review of risks and benefits. Food Control 31: 251-262. doi :10.1016/ j.foodcont.2012.09.03

Conesa C, Rota C, Castillo E, Perez MD, Calvo M, Sanchez L (2010) Effect of heat treatment on the antibacterial activity of bovine lactoferrin against three food borne pathogens. Int J Dairy Technol 63: 209-215.doi: 10.1111/j.1471-0307.2010.00567.x

Corrêa APF, Daroit DJ, Coelho J, Meira SM, Lopes FC, Segalin J, Risso PH, Brandelli A (2011) Antioxidant, antihypertensive and antimicrobial properties of ovine milk caseinate hydrolyzed with a microbial protease. J Agr Food Chem 91: 2247-2254. doi:10.1002/ jsfa. 4446

Deeth H C,Fitzgerald C H, Wood A F (1975) A convenient method for determining the extent of lipolysis in milk. Aust J Dairy Technol 30:109-111

Drider D, Fimland G, Héchard Y, McMullen LM, Prévost H (2006) The continuing story of class IIa bacteriocins. Microbiol Mol Biol 70:564582. doi: 10.1128/MMBR.00016-05

Dumitraşcu L, Stănciuc N, Stanciu S, Râpeanu G (2012) Thermal inactivation of lactoperoxidase in goat, sheep and bovine milk - A comparative kinetic and thermodynamic study. J Food Eng 113: 4752.doi.org/10.1016/j.jfoodeng.2012.05.028

DupasC, Adt I, Cottaz A, Boutrou R, Molle D, Jardin J, Jouvet T, Degraeve $P$ (2009) A chromatographic procedure for semi-quantitative evaluation of caseinphosphopeptides in cheese. Dairy Sci Technol 89: 519-529.doi: $10.1051 / \mathrm{dst} / 2009027$

Farnaud S, Evans RW (2003) Lactoferrin: a multifunctional protein with antimicrobial properties. Molecul Immunol 40: 395-405. doi:10.1016/S0161-5890(03)00152-4

Fontan MCG, Franco I, Prieto B, Tornadijo ME, Carballo J (2001) Microbiological changes in 'San Simoon' cheese throughout ripening and its relationship with physico-chemical parameters. Food Microbiol 18: 25-33.doi:10.1006/fmic.2000.0351

Franco I, Prieto B, Urdiales R, Fresno JM, Carballo J (2001) Study of the biochemical changes during ripening of Ahumado de Aliva cheese: a Spanish traditional variety. Food Chem 74: 463-469. doi: 10.1016/ S0308-8146(01)00164-9

Galli BD, Baptista DP, Cavalheiro FG, Negrab F, Eberlin M N, Gigante ML (2019) Peptide profile of Camembert-type cheese: Effect of heat treatment and adjunct culture Lactobacillus rhamnosus GG. Food Res Int 234:71-75. doi:10.1016/j.ijfoodmicro.2016.06.025

Gebreyowhans S, Zhang S, Pang X, Yang B, Wang T, Wu Z, Lu J, Iaping J (2020) Changes in texture, composition and sensory characteristics of Camembert cheese made from a mixture of goat milk and cow milk during ripening. Int J Dairy Technol. doi: 10.1111/14710307.126990

Gérard Y (2015) Contractualisation et modes de coordination dans la filière laitière. Économie rurale 345: 87-100. doi: 10.4000/ economierurale. 4580 
Gobbetti M, Morea M, Baruzzi F, Corbo M R, Matarante A, Considine T, DiCagno R, Guinee T, Foxd PF (2002) Microbiological, compositional, biochemical and textural characterisation of Caciocavallo Pugliese cheese during ripening. Int Dairy J 12: 511 523

Gonzalez J, Mas M, Tabla R, Moriche J, Roa I, Rebollo JE, Cáceres P (2003) Autochthonous starter effect on the microbiological, physicochemical and sensorial characteristics of Ibores goat's milk cheeses. Le Lait 83:193-202. doi : 10.1051/lait:2003009

Gripon J C, Desmazeaud M J, Lebars D, Bergere J L (1975) Etude du rôle des microorganismes et des enzymes au cours de la maturation des fromages : II. Influence de la présure commerciale. Le Lait 55:502516. doi : 10.1051/lait:197554828

Guerra-Martínez J A, Montejano J G, Martín-del-Campo S T (2012) Evaluation of proteolytic and physicochemical changes during storage of fresh Panela cheese from Queretaro, Mexico and its impact in texture. CYTA-J Food 10: 296-305.doi: 10.1080/ 19476337.2011.653791.

JORADP (Journal officiel de République Algérienne Démocratique et Populaire) (2014) Arrêté 17 du 17-12-2013 relatif à la détermination de la matière grasse dans le fromage. JORADP $n^{\circ} 67$ du 12-11-2014

JORADP (Journal Officiel de la République Algérienne Démocratique et Populaire) (2017) n³9 du2 juillet 2017. Arrêté interministériel du 2 Moharram 1438 correspondant au 4 octobre 2016 fixant les critères microbiologiques des denrées alimentaires, pp 13-15

Joffin C, Joffin J N (1999) Microbiologie alimentaire. CRDP d'Aquitaine, 5th edn, Bordeaux, pp 213-215

Kali S, Benidir M, Ait Kaci K, Belkheir B, Benyoucef MT (2011) Situation de la filière lait en Algérie: Approche analytique d'amont en aval. Livest Res Rural Dev 23:1-12

Kirdar SV, Kursun-Yurdakul O, Kalit S, Kalit MT (2018) Microbiological changes throughout ripening of Keş cheese. J. Cent. Eur. Agric 19:6171. doi: /10.5513/JCEA01/19.1.2024

Laemmli V K (1970) Cleavage of structural proteins during the assembly of the head of bacteriophage T4. Nature 227:680-685

Leclercq-Perlat M N, Oumer A, Buono F, Bergere J L, Spinnler H E, Corrieu G (2000) behavior of Brevibacterium linens and Debaryomyces hansenii as ripening flora in controlled production of soft Smear Cheese from reconstituted milk: Protein Degradation. J Dairy Sci 83:1674-1683

Leclercq-Perlat M N, Buono F, Lambert D, Latrille E, Spinnler H E, Corrieu G (2004) Controlled production of Camembert-type cheeses. Part I: Microbiological and physicochemical evolutions. J Dairy Res 71: 346-354. doi: 10.1017/S0022029904000196

Lenoir J (1963) La flore microbienne du Camembert et son évolution au cours de la maturation. Le Lait 43: 262-270. doi: 10.1051/ lait:1963425-42611

Lignitto L, Segato S, Balzan, S, Cavatorta V, Oulahal N, Sforza S, Degraeve P, Galaverna, G, Novelli E (2012) Preliminary investigation on the presence of peptides inhibiting the growth of Listeria innocua and Listeria monocytogenes in Asiago d'Allevo cheese. Dairy Sci \& Technol 92: 297-308. doi: 10.1007/s13594-012-0057

Lowry O H, Rosebrough N J, Farr A L, Randall R J (1951) Protein measurement with the Folin phenol reagent. J Biol Chem 193: 265275

Mamine F, Bourbouze, Arbouche F (2011) La production laitière locale dans les politiques de la filière lait en Algérie. Cas de la wilaya de Souk Ahras. Livest Res Rural Dev 23: 1-2

Mane A, McSweeney PLH (2019) Proteolysis in Irish farmhouse Camembert cheese during Ripening. J Food Biochem. doi.org/10.1111/jfbc.13101

McSweeney PLH, Fox PF, Lucey J, Jordan KN, Cogan TM (1993) Contribution of the indigenous microflora to the maturation of
Cheddar cheese. Int Dairy J 3: 613-634. doi: 10.1016/0958-6946 (93) $90104-8$

Meribai A, Jenidi R, Hammouche Y, Bensoltane A(2017) Physico-chemical characterization and microbiological quality evaluation of klila, an artisanal hard dried cheese from Algerian's arid areas: Preliminary study. J New Sci Agric and Biotech 40: 2169-2174

Motta A S, Brandelli A (2002) Characterization of an antibacterial peptide produced by Brevibacterium linens. J Appl Microbiol 92:63-70. doi:10.1046/j.1365-2672.2002.01490.x

Mourgues R, Vassal L, Auclair J, Mocquot G (1977) Origine et développement des bactéries coliformes dans les fromages à pâte molle. Le Lait 57: 131-149. doi: 10.1051/lait:1977563-5645

Nalepa B, Olszewskaa M A, Markiewiczb L M (2018) Seasonal variances in bacterial microbiota and volatile organic compounds in raw milk. Int J Food Microbiol 267:70-76. doi:10.1016/ j.ijfoodmicro.2017.12.024

Nguyen Thi P, Dupas C, Adt I, Degraeve P, Ragon M, Missaoui MF, Novelli E, Segato S, Dong PT, Oulahal N (2013) Partial characterisation of peptides inhibiting Listeria growth in two Alpine cheeses. Dairy Sci Technol 94: 61-72. DOI: 10.1007/s13594-0130141-6

Orlyuk YT, Stepanishchev MI (2014) Assessment of proteolysis and lipolysis intensity in pechersky cheese ripening in the presence of Penicillium camemberti and Penicillium roquefortimolds. Foods and Raw Mater 2: 36-39. doi: 10.12737/4128

Ortolani MBT, Moraes PM, Perin LM, Vicosa GN, Carvalho KG, Silva JA, Nero LA (2010) Molecular identification of naturally occurring bacteriocinogenic and bacteriocinogenic-like lactic acid bacteria in raw milk and soft cheese. J Dairy Sci 93: 2880-2886. doi: 10.3168/ jds.2009-3000

Polychroniadou A (1988) A simple procedure using trinitrobenzenesulphonic acid for monitoring proteolysis in cheese. J Dairy Res 55: 585-596. doi: 10.1017/S0022029900033379

Pritchard S, Phillips M, Kailasapathy K (2010) Identification of bioactive peptides in commercial Cheddar cheese. Food Res Int 43: 15451548. doi: $10.1016 /$ j.foodres.2010.03.007

Randoin L, Jourdan C (1952) Détermination des teneurs en eau et matière sèche, en calcium et en phosphore de deux variétés de fromages à pâte demi-dure et à moisissures internes. Le Lait 32 : 481-485. doi: https://doi.org/10.1051/lait:195231818

Richard J, Zadi, H (1983) Inventaire de la Flore Bactérienne dominante des Camemberts fabriqués avec du lait cru. Le Lait 63: 25-42. doi: org/10.1051/lait:1983623-6243

Rutzinski JL, Marth EH, Olson NF (1979) Behavior of Enterobscterserogenes and Hafnia Species during the Manufacture and Ripening of Camembert Cheese. J Food Prot 42: 790-793. doi:10.4315/0362-028X-42.10.790

Saboya LV, Goudédranche H, Maubois JL, Lerayer ALS, Lortal S (2001) Impact of broken cells of lactococci or propionibacteria on the ripening of Saint-Paulin UF-cheeses: extent of proteolysis and GCMS profiles. Le Lait 81: 699-713

Sahraoui Y, Fayolle K, Leriche F, Le Flèche-Matéos A, Sadoun D (2015) Antibacterial and technological properties of Lactococcus lactis ssp. lactis KJ660075 strain selected for its inhibitory power against Staphylococcus aureus for cheese quality improving. J Food Sci Technol 52: 7133-7142. doi: 10.1007/s13197-015-1845-9

Samelis J, Lianou A, Kakouri A, Delbes C, Rogelj I, Bojana BM, Montel MC (2009) Changes in the Microbial Composition of Raw Milk Induced by Thermization Treatments Applied Prior to Traditional Greek Hard Cheese Processing. Journal Food Prot 72: 783-790.

Seifu E, Buys EM, Donkin EF (2005) Significance of the lactoperoxidase system in the dairy industry and its potential applications. Trends Food Sci Technol 16: 137-154. doi:10.1016/j.tifs.2004.11.002 
Spike PW, Freeman A E (1967) Environmental influences on monthly variation in milk constituents. J Dairy Sci 50: 1897-1904

Sulieman EAM, Mohamed Ali RA, Abdel Razig KA (2012) Production and Effect of Storage in the Chemical Composition of Mozzarella Cheese. Int J Food Sci Nutr Engin 3: 21-26.doi: 10.5923/j.food.20120203.02

Trujillo AJ, Guamis B, Carretero C (1997) Hydrolysis of Caprine $\beta$-Casein by Plasmin. J Dairy Sci 80: 2258-2263. doi:10.3168/jds.S00220302 (97)76174-5

Upreti P, Metzger LE, Hayest KD (2006) Influence of calcium and phosphorus, lactose, and salt-to-moisture ratio on cheddar cheese quality: Proteolysis duringripening. J Dairy Sci 89:444-453

Vajiheh F (2012) Milk Proteins-derived antibacterial peptides as novel functional food ingredients. Ann Biol Res 3: 2520-2526
Van Hekken DL, Tunick MH, Tomasula, PM, Francisco J, Corral M, Gardea A (2007) Mexican Queso Chihuahua: rheology of fresh cheese. Int J Dairy Technol 60: 5-12. doi: 10.1111/j.14710307.2007.00291.x

Visser S (1993) Proteolytic Enzymes and Their Relation to Cheese Ripening and Flavor. J Dairy Sci: 329-350. doi:10.3168/jds.s0022-0302 (93)77354-3

Wan K, Harmark BE, Davidson AJ, Hillier JB, Gordon A, Wilcock MW, Hickey MJ (1997) Coventry-Inhibition of Listeria monocytogenes by piscicolin 126 in milk and Camembert cheese manufactured with a thermophilic starter. J Appl Microbiol 82: 273-280 